\title{
CHANGING RULES OF EVIDENCE IN THE FEDERAL COURTS
}

At common law, ${ }^{1}$ interested witnesses ${ }^{2}$ were not permitted to testify in their own behalf in civil ${ }^{3}$ or criminal ${ }^{4}$ cases. Spouses, for additional reasons of policy, ${ }^{5}$ were held incompetent to testify either for or against each other. ${ }^{6}$ Prior to statutory modifications of these common law rules of competency ${ }^{7}$ there was unani-

x Prior to the development of the modern jury trial, questions of competency of witnesses did not arise since the jury found a verdict of their own knowledge. For the development of the jury, see Hinton, Cases on Evidence (2d ed. I93I), c. I, \& x; x Wigmore, Evidence (2d ed. I923), $985 ; 9$ Holdsworth, History of English Law (1926), r78-185.

${ }^{2}$ The interest disqualification was based on the theory that interested persons were biased and hence not credible; also the courts were unwilling to subject the interested witness to the temptation to commit perjury. New Arcade v. Owens, 258 Fed. 965 (D.C. Ct. App. rgIg); Skahen v. Strauss, 199 Ill. App. 403 (1916); Gilbert, Evidence (4th ed. 1777) I Ig. For some exceptions to the interest disqualification because of necessity see United States v. Clark, 96 U.S. 37,24 L. Ed. 696 (1877). Parmelee v. McNulty, I9 Ill. 556 (1858); County v. Leidy, I0 Pa. 45 (1848).

To disqualify, the interest had to be "some legal, certain and immediate interest in the result of the suit itself, or in the record thereof as an instrument of evidence to support his own claims." Poe v. Dorrah, 20 Ala. 288 ( 1852 ); Evans v. Eaton, 7 Wheat. (U.S.) 356, 5 L. Ed. 472 (I822); Ackman v. Potter, 239 Ill. 578, 88 N.E. 23 I (1909).

Parties to the suit were of course directly interested as thus defined. For others who were considered disqualified because of interest, see I Wigmore, supra note $\mathrm{x}, 996 \mathrm{ff} ; 5$ Chamberlayne, Modern Law of Evidence (I9I6), § 3669; Jones, Evidence (3d ed. rg24), c. 20.

3 By ${ }_{15} 82$ the rule in civil cases was well established, Dymoke's Case, Savile 34 , pl. r8. Stein v. Bowman, 13 Pet. (U.S.) 209, 10 L. Ed. I29 (r839); Marks v. Butler, 24 Ill. 568 (1860); Frear v. Everton, 20 Johns. (N.Y.) I42 (I822); Radtke v. Taylor, Io5 Ore. 559, 210 Pac. 863 (1922); I Wigmore, supra note I, 990 ff.

4 Whelchell v. State, 23 Ind. 89 (1864); Harwell v. State, ro Lea (Tenn.) 544 (1882). The disqualification developed later in criminal cases than in civil. $x$ Wigmore, supra note $\mathrm{I}, 995$ n. 42; 9 Holdsworth, supra note 1,196 . The complaining witness or prosecutor was not excluded under the rule since neither were parties to the record. Best, Evidence (4th ed. 1866), 238.

$s$ The reasons usually given: I. Likelihood of false testimony because of a common interest. Merriam v. Hartford Ry. Co., 20 Conn. 354 (1850); Gilbert, Law of Evidence (4th ed. 1777), 133. 2. Metaphysical unity. Coke Litt. 6b, Wigmore, Cases on Evidence (3d ed. 1932), i 16. 3. Public policy to prevent marital disharmony. Mitchinson v. Cross, 58 Ill. 366 (r87I); Bird v. Davis, 14 N.J. Eq. 467 (r862).

'Civil cases: Stein v. Bowman, I3 Pet. (U.S.) 209, ro L. Ed. I29 (I839); Schreffler v. Chase, 245 Ill. 395,92 N.E. 272 (1910).

Criminal cases: Jin Fuey Moy v. United States, 254 U.S. I89, 4 r Sup. Ct. 98, 65 L. Ed. 214 (x920); Barber v. People, 203 Ill. 543 , 68 N.E. 93 (rgo3); Wilke v. People, 53 N.Y. 525 (r873). That the incompetency was absolute and did not rest on privilege see Stein v. Bowman, 13 Pet. (U.S.) 209 , xo L. Ed. 129 (1839); Ex parte Beville, 58 Fla. 170, 50 So. 685 (1909); but see Ficken v. State, 97 Ga. 813 , 25 S.E. 925 ( 1895 ).

7 a. The first outstanding attack on the exclusionary rules of evidence was made by Bentham in 1827 . Bentham, Rationale of Judicial Evidence, bk. IX, pt. 3; I Wigmore, supra, note I, 997, 1002; Appleton, Evid. (1860), c. I, 4; Phil. Evid. (5th Am. ed.), 24 ff.

b. Civil Cases.

In England the interest disqualification for witnesses was not removed until I843 (St. 6 \& 7 
mous agreement both among the various states and between federal and state courts as to the inadmissibility of such evidence. ${ }^{8}$

In civil cases, this uniformity between federal and state courts as to competency of witnesses continued despite the legislative abolition by the states of the common law testimonial disqualifications, 9 by operation of conformity statutes ${ }^{\text {to }}$ directing the federal courts to follow state rules of evidence.

Vict. c. 85 ) by Lord Denman's Act, which specifically excepted parties to the suit and spouses. Parties to the action were not made competent in civil cases until I85I. St. I $_{4}$ \& ${ }_{5}$ Vict. c. 99.

In the United States the development came later. I Wigmore, id., Ioo4, note 4 and $\S 488$. Parties and witnesses were not made competent in the Federal courts until r864. Rev. Stat. $\S 858,28$ U.S.C.A. $\S 63$ r (as amended). Monongahela National Bank v. Jacobus, rog U.S. 275, 3 Sup. Ct. 219, 27 L. Ed. 935 (1883); De Beaumont v. Webster, 8 I Fed. 535 (C.C.A. 3d I897). For other cases see 28 U.S.C.A. 63 I.

Today the disqualification has everywhere disappeared. I Wigmore, $i d$., I004, the various state statutes being listed at p. 870 .

c. Criminal Cases.

The abolition of the interest disqualification in criminal cases came later both in America and England. For suggested explanations see I Wigmore, $i d$., Ioog.

In England the defendant was not competent until 1898 . St. 6r \& 62 Vict. c. 36 , § 1 ; Rex v. Wheeler, [xgז6] I K.B. 283 . Best, Evidence (8th ed. I9ז6), $\$ 822 \mathrm{~A}$.

In the federal courts the defendant was made competent in 1878 . 20 Stat. 30 (I878), 28 U.S.C.A. $63^{2}$ (I928). For state statutes see I Wigmore, id., $\S 488$.

d. Spouses.

Incompetency of spouses was not abolished by statute in civil cases in England until 1853 (St. $\mathrm{r} 6 \&$ I 7 Vict. c. $83, \S 4 ; 32 \& 33$ Vict. c. $68, \S 3,1869$ ), and in criminal cases not until 1898 (St. 6r \& 62 Vict. c. $36, \S \mathrm{I}$ ) all of which are reprinted in I Wigmore, supra, note I, § 488.

In the United States the removal occurred later. I Wigmore, $i d$., ro36. Civil Cases: In re Domenig, I 28 Fed. $x_{4} 6$ (D.C.Pa. I904); Brown v. Norton, 67 Ind. 424 (I879); Shepard v. Parker, 97 Me. 86, 53 Atl. 879 (rgo2); Evans v. Evans, $x_{55}$ Pa. 572, 26 Atl. 755 (1893). Criminal Cases: Walker v. State, 34 Fla. I67, I6 So. 8 (I894); Commonwealth v. Moore, r62 Mass. 44I, 38 N.E. 1 I 20 (I894); People v. Hovey, 92 N.Y. 554 (1883); State v. Reynolds, 48 S.C. 384 , 26 S.E 679 ( 1896 ) (spouse permitted to testify against her husband).

Some states require the consent of the other spouse. In re Holt, 56 Minn. 33 ( 1893 ); Hubbell v. Grant, 39 Mich. 64I (I878); Stanley v. Stanley, 27 Wash. 570 (1902); State v. Willis, IIg Mo. 485 (I894).

${ }^{8}$ See cases supra, note 7 .

9 See supra, note 7 .

${ }^{10}$ All the applicable statutes will be included in this note for convenient reference.

a. I2 Stat. 588, Act of July I6, I862, c. I89, § I; as amended Rev. Stat. 858 (Igo6), 28 U.S.C.A. $63 \mathrm{r}\left(\mathrm{x}_{228} 8\right)$ :

"The competency of a witness to testify in any civil action, suit or proceeding in the courts of the United States shall be determined by the laws of the State or Territory in which the court is held."

In its original wording the section was construed not to apply to federal criminal trials. The Abbotsford, 98 U.S. 440, 25 L. Ed. 168 (I878); Logan v. United States, I44 U.S. 263, 30I ff., I2 Sup. Ct. 6I7, 36 I. Ed. 429 (I892); Hendrix v. United States 2 I9 U.S. 79, 3 I Sup. Ct. I93, $55 \mathrm{~L}$. Ed. xo2 (Igro). The same is true of the section in its present form. Adams v. United States, 259 Fed. 214 (C.C.A. 8th roxg).

b. I7 Stat. 197 , Act of June $x, 1872$, c. $255, \S 5,28$ U.S.C.A. 724 (x928):

"The practice, pleadings and forms and modes of proceeding in civil cases, other than equity or admiralty causes, in the district courts, shall conform, as near as may be, to the practice, 
In criminal cases, on the other hand, a divergence soon appeared due to decisions which prevented state statutory liberalizations of rules of competency from being reflected in the federal courts, ${ }^{x x}$ by holding that the various conformity acts did not apply to criminal prosecutions. ${ }^{{ }^{2}}$ Conflicting interpretations of these and other applicable Supreme Court cases, however, created some uncertainty as to the law which should control, ${ }^{13}$ though all agreed on the negative proposition that the law which did govern competency in federal criminal cases was not affected by subsequent state statutes..$^{\mathrm{I}}$ Three bodies of law were suggested: (I) The common law rules of evidence fixed unchangeably (in the absence of further congressional action) as they existed in 1789 , the date of the passage of the Judiciary Act. ${ }^{15}$ This view was followed by the majority of

pleadings, and forms and modes of proceeding existing at the time in like causes in the courts of record of the State within which such district courts are held, any rule of court to the contrary notwithstanding."

By its terms this section applies only to civil proceedings.

c. I Stat. 92 , Act of Sept. $24, \times 789$, c. $20, \S 34$, as amended Rev. St. 721 (I878), 28 U.S.C.A. 725 (I928):

"The laws of the several states, except where the Constitution, treaties, or statutes of the United States otherwise require or provide shall be regarded as rules of decisions in trials at common law in the courts of the United States, in cases where they apply."

This section as construed by the federal courts does not apply to rules of evidence in criminal prosecutions. United States v. Reid, I 2 How., (U.S.) $36 \mathrm{I}$, I3 L. Ed. I023 (I85I); Logan v. United States, I44 U.S. 263, 300, I2 Sup. Ct. 617, 36 L. Ed. 429 (I892); American Ry. Express Co. v. Rowe, I4 F. (2d) 269 (C.C.A. Ist 1926), cert. denied 273 U.S. 743,47 Sup. Ct. 336,7 I L. Ed. 869 (Ig27).

The courts are divided on the question of whether this section compels them to follow state rules of evidence in civil cases. Holding that it does are Wilcox v. Hunt, $x_{3}$ Pet. (U.S.) 378 , xo L. Ed. 209 (1839); Gormley v. Clark, I34 U.S. 338, 1o Sup. Ct. 554, 33 L. Ed. 909 (r89o); Stewart v. Morris, 89 Fed. 290 (C.C.A. 7 th I898); Von Crome v. Traveler's Ins. Co. II F.(2d) 350 (C.C.A. 8th 1926). For other cases see 28 U.S.C.A. $\$ 725$ (I928), note 84. Contra, explaining away the Supreme Court decisions, are Union Pacific Rr. Co. v. Yates, 79 Fed. 584 (C.C.A. 8th 1897); Gilbert v. American Surety Co., x2r Fed. 499 (C.C.A. 7th IgO2), cert. denied Igo U.S. 560, 23 Sup. Ct. 855, 47 L. Ed. I 184 (r903); Mankato v. Barber Asphalt Paving Co., I42 Fed. 329 (C.C.A. 8th 1905). For other cases see 28 U.S.C.A. 725, note 83.

d. For other related statutes and statutory chronology of those cited above see Sweeney, Federal or State Rules of Evidence in Federal Courts, 27 Ill. L. Rev. 394, 400 (r932).

II Thus in Fitter v. United States, 258 Fed. $5_{67}$ (C.C.A. 2 d $x 9$ ro), the wife of the defendant was not permitted to testify in his behalf in the federal courts, though she would have been competent in a prosecution in the state court under People v. Hovey, 92 N.Y. 554 (I883).

12 Cases and statutes, supra note ro.

${ }^{23}$ See cases infra, notes 15, I6, I7. The leading Supreme Court cases will be discussed in detail below. See also Sweeney, Federal or State Rules of Evidence in Federal Courts, 27 Ill. L. Rev. 394, 400 (1932).

${ }^{4}$ See cases infra, notes 15,16 , I7.

${ }_{x}$ The cases following this view purport to rely upon United States v. Reid, 2 How. (U.S.) $361,13 \mathrm{~L}$. Ed. 1023 ( $185 \mathrm{I}$ ). The validity of this interpretation will be discussed subsequently. 
courts. ${ }^{16}$ (2) The rules of evidence fixed unchangeably (in the absence of further congressional legislation) as they existed in the individual state at the time of its admission into the Union, thus including whatever statutory changes in the common law the territorial legislatures had enacted before such admission. ${ }^{17}$ (3) A third view refused to regard the rules of evidence as crystallized into immobility and declared that the courts had power to modify the common law rules (even in the absence of Congressional action) when necessitated by changing societal conditions. ${ }^{\mathrm{x}}$

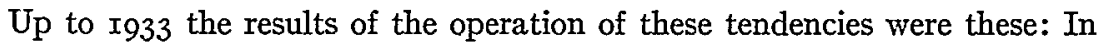
civil cases virtually all the states had abolished the common law disqualifications of witnesses and spouses. Since this was reflected in the federal courts by the conformity acts, there was uniformity both among the federal courts themselves and between the federal and state courts as to rules of competency in civil cases. In criminal cases state statutes abolishing incompetency were not thus reflected, and since three dissimilar views were adopted as stated above, conflicting rules of competency prevailed not only between federal and state courts but among the various federal courts themselves. This divergence was not bridged by federal legislation. ${ }^{19}$

At the October 1933 term, in Funk v. United States, ${ }^{20}$ the Supreme Court conclusively affirmed the power of the federal courts to modify the common law rules of evidence without statutory assistance by Congress, and definitely re-

${ }^{6}$ United States v. Hall, 53 Fed. 352 (D.C.Pa. I892); United States v. Hughes, 175 Fed. 238 (D.C.W.D.Pa. I9Io); Maxey v. United States, 207 Fed. 327 (C.C.A. 8 th $\mathrm{rg}^{1} 3$ ); Fisher v. United States, $3_{2}$ F. (2d) 602 (W.C.C.A. $4^{\text {th }}$ I929); Barton v. United States, 25 F. (2d) 967 (C.C.A. $4^{\text {th }}$ 1928); Scaffidi v. United States, 37 F. (2d) 203 (C.C.A. Ist r930).

17 Brown v. United States, 233 Fed. 353 (C.C.A. 6th I9I6) (dictım); McCoy v. United States, 247 Fed. 86I (witness convicted of a felony held competent because the territorial legislature, prior to the admission of the state into the Union, had removed the disqualification); Ding v. United States, 247 Fed. I2 (C.C.A. 9th I9I8) (atheist held competent for the same reason); Rendleman v. United States, r8 F. (2d) 27 (C.C.A. 9th 1927) (wife held competent for same reason).

${ }^{18}$ Rosen v. United States, 245 U.S. 467,38 Sup. Ct. I48, 62 L. Ed. 406 (IgI8). The authority of this case was considered to be questionable in view of subsequent cases. See Leach, State Law of Evidence in Federal Courts, 43 Harv. L. Rev. 554, 565 (r930). Funk v. United States, 290 U.S. 37x, 54 Sup. Ct. 2 I 2 (1933) affirms the Rosen case, however. Both will be discussed in detail below.

19 Where Congress has passed specific legislation, such provisions control, Cohen v. United States, 214 Fed. 23 (C.C.A. 9th I9I4), cert. denied 235 U.S. 696, 35 Sup. Ct. x99; Parker v. United States, 3 F. (2d) 903 (C.C.A. 9th I925). For example, the defendant in a criminal case is made a competent witness in the federal courts regardless of the state law by 20 Stat. 30 ( 1878 ), 28 U.S.C.A. $\$ 632$ (I928).

In 1887 Congress made competent the spouse of a defendant in a criminal prosecution for bigamy. Act of March 3, 1887, c. $397, \S 1,28$ U.S.C.A. 633 (1928). This was the sole legislation on the subject during the period.

${ }^{20}$ Funk v. United States, 290 U.S. 37I, 54 Sup. Ct. 212 (I933), where a wife was permitted to testify for her husband in a criminal case. At common law she would have been incompetent. 
jected the views which held the rules of competency were fixed unalterably as of any one time.

Funk v. United States will therefore have a threefold effect on rules of evidence in criminal cases: ( $\mathrm{I}$ ) It will level off the differences between federal and state courts on rules of competency, by bringing the federal law into conformity with those of a great majority of the states. (2) It will also make for uniformity among the various federal courts since it definitely overrules the view that the federal rules of evidence are those which existed in each state at the time of its admission into the Union. (3) It frees the federal courts from the anomalous necessity, under modern conditions, of following the common law rules of 1789 , and by rejecting the doctrine that such adherence was mandatory, lays down a principle which will permit further development in the same direction. The court based this principle, however, upon an interpretation of the prior Supreme Court cases which resulted in the uncertainty and conflict already described. In order to permit further growth without the confusion which attended that growth heretofore, and because of its importance in the future development of the law of evidence the principle requires a clear enunciation and restatement.

The primary cause of the confusion was a misunderstanding of the scope of the decision in the case which first raised the direct question of the proper rules of evidence to be applied in criminal cases in the federal courts, United States $v$. $\operatorname{Reid}^{2 \mathrm{x}}$ (decided in $\mathrm{I8} 5 \mathrm{I}$ ). This was a criminal prosecution brought in a federal court in Virginia, and involved the competency of a witness to testify for the defendant. The witness would have been incompetent at common law, but under a statute passed in Virginia some sixty years after the federal Judiciary Act he became competent to testify in the state courts. Thus the question was presented whether such state statute would be given any effect in the federal courts. The Judiciary Act of $I 789$ provided that:

The laws of the several States ... . shall be regarded as rules of decision in trials at common law in the courts of the United States, in cases where they apply.

The Supreme Court decided the Act did not apply to criminal cases ${ }^{22}$ and that the witness was incompetent, holding that Congress by this section of the Judiciary

${ }^{21}$ United States v. Reid, 12 How. (U.S.) $36 \mathrm{x}, \mathrm{r}_{3}$ L. Ed. I023 (1851).

$2 z$ We are not interested here in the question of the correctness of this interpretation by the Reid case. I Wigmore, supra note $\mathrm{I}, \S 6$ calls this an indefensible construction. See also Leach, State Law of Evidence in the Federal Courts, 43 Harv. L. Rev. 554, 556 (r930). Chief Justice Taney reasoned that Congress intended by the act to confer jurisdiction on the federal courts, without which they could not have administered the laws of the states, and that the wording would have to be more definite to include the rules of evidence of the states, since so to hold would be to "place the criminal jurisprudence of one sovereignty under the control of another." From that premise he reasoned by a process of elimination that Congress could not have intended the common law of England to control, nor the common law of the colonies, and that "the only known rule upon the subject which can be supposed to have been in the minds of the men who framed these acts of Congress, was that which was then in force in the respective states [at the time of the Judiciary Act of ${ }^{7} 789$ ], and which they were accustomed to see in daily and familiar practice in the state courts." I2 How. (U.S.) $36 \mathrm{x}, 365, \mathrm{r}_{3} \mathrm{~L}$. Ed. 1023, 1025 (I85I). 
Act had directed the federal courts to apply the rules of evidence in force "in the respective states" at the time that Act was passed, $x 789$, and that the common law rules so adopted and established could not be changed by subsequent state legislation.

This decision was implicitly understood to mean that in the absence of a new statutory direction by Congress the rules of evidence were fixed unchangeably as they existed in $r 789$. The line of reasoning by which this result was reached may be articulated thus:

The Reid case decided ( $x$ ) that Congress had in the Judiciary Act directed the federal courts to follow the common law rules of competency of 1789 , and (2) that subsequent state statutes could not change those rules.

Abolition of incompetency was effected solely through state statutes which under (2) left the federal rule unchanged.

Any decision which would attempt to abolish a common law disqualification without action by Congress, therefore, would be erroneous, since it would be contrary to the Reid case and would be disregarding the Judiciary Act.

Therefore the rules of evidence in the federal courts are fixed unchangeably as they were in 1789 unless Congress chooses to modify them by statute.

A court which so understood the Reid case would consequently feel compelled to overrule it, in part, to justify a change in the common law rules of competency. And conversely, a court which, in abolishing a common law rule of competency, felt it necessary to overrule the Reid case, would implicitly indicate that it had so interpreted the Reid case, whether it had articulated the line of reasoning or not. The first Supreme Court to clearly demonstrate this implicit analysis was Rosen 0 . United States ${ }^{23}$ in which the court said:

While the decision in United States v. Reid has not been specifically overruled, its authority must be regarded as seriously shaken. ..... ${ }^{24}$

${ }^{23}$ Rosen v. United States, 245 U.S. 467 , 38 Sup. Ct. 148,62 L. Ed. 406 (rgr8). The question raised was as to the competency, in a federal court in New York, of a witness previously convicted of a felony in the state courts of New York. The court believed it was overruling the common law rule by holding the witness competent and decided the question "in the light of sound reason."

Professor Hinton points out in 22 Ill. L. Rev. 545, 55I (I928) that the case could have been decided upon the ground that the conviction was by a court of a different sovereignty and that by the common law rule such a conviction did not make the witness incompetent, citing Brown v. United States, ${ }_{233}$ Fed. 353 (C.C.A. 6th I9I6), L.R.A. I917 A, $\mathrm{II}_{33}$ (note).

${ }^{24}$ The Rosen case relies upon two prior Supreme Court decisions to justify its conclusion that the Reid case was not sound law, discerning in them an inconsistency with the holding in the Reid case:

(x) Logan v. United States, I44 U.S. 263 , r2 Sup. Ct. 6I7, 36 L. Ed. 429 (I892), which raised the converse of the issue in the Rosen case, the witness being competent at common law, but incompetent under a statute of Texas passed after it had come into the Union. While it was a republic, Texas had adopted the common law in general terms. In upholding the competency of the witness in the federal court of Texas in a criminal trial, the Supreme Court opinion said:

". . . . the competency of witnesses in criminal trials in the courts of the United States held within the State of Texas is not governed by a statute of the State which was first enacted in 
Funk v. United States confirms this analysis. 25 By so interpreting the Reid case however, Rosen $v$. United States presented a distorted picture of the decision (which the Funk case perpetuates), since it implied that the Reid case intended to anchor the laws of evidence as they existed in $I 789$. This, it may be suggested, the Reid case did not purport to do, and to so understand the decision demonstrates a subtle misconception of the nature of the common law which has confused the cases in the past and may cause trouble in the future. And it creates the apparent incongruity of state statutes automatically becom-

I 858 , but, except so far as Congress has made specific provisions upon the subject, is governed by the common law, which, as has been seen, was the law of Texas before the passage of that statute and at the time of the admission of Texas into the Union as a state."

All the cases which adopt the view that competency is governed by the rules of evidence as they existed in the individual states at the time of their admission to the Union (see supra, uote 17) rely upon the italicized part of the quotation given above. When read in its context, however, this passage does not seem to justify that interpretation, though there is some difference of opinion on the point. Professor Hinton in 22 Ill. L. Rev. 545, 55I (1928) suggests that the case does not conflict with United States v. Reid. Acc. Leach, State Law of Evidence in the Federal Courts, 43 Harv. L. Rev. 554, 562 (1930); Justices Van Devanter and McReynolds, dissenting in Rosen v. United States, 245 U.S. $467,473,38$ Sup. Ct. 148, 15I, 62 L. Ed. 406 , 408 (I9I8). A contrary view is taken by Sweeney, Federal or State Rules of Evidence in Federal Courts, 27 Ill. L. Rev. 394, 4I4 (I932), and Justice Clarke speaking for the majority in Rosen v. United States, id., 470.

(2) Benson v. United States, 146 U.S. $325, \mathrm{x}_{3}$ Sup. Ct. 6o, 36 L. Ed. $99 x$ ( 1892 ), which involved the competency of a joint indictee as a witness for the proseculion in a separate trial of his co-indictee in a federal court. The Reid case had raised the same question with regard to a witness called by the defendant. In answering the defendant's contention that the Reid case was decisive of the case before it, the court in the Benson case said:

"The precise question in that case [United States v. Reid] was as to the right of the defendant to call his co-defendant, and not that of the government to call the co-defendant, and a distinction has been taken between the two cases..... And as the distinction prevailed, whether founded on satisfactory reasons or not, it is sufficient to justify us in holding that that case is not decisive of this. .... We do not feel ourselves, therefore, precluded by that case from examining this question in the light of general authority and sound reason."

The court then pointed out the great changes in competency wrought by statute, all tending toward a liberalization of the strict common law rules, and continued: "The spirit of this legislation has controlled the decisions of the courts. . . ." The court's lengthy discussion of this point may indicate an incipient dissatisfaction with the state of the existing rules of evidence, but the decision does not seem to overrule the Reid case. The court was only deciding what the common law rule was on the question before it.

${ }_{25}$ Funk v. United States, 290 U.S. 37r, 54 Sup. Ct. 212, 214 (r933) adopts the interpretation of the Reid case given in Rosen v. United States:

". . . . it is plain enough that the ultimate doctrine announced is that in the taking of testimony in criminal cases, the federal courts are bound by the ralles of the common law as they existed at a definitely specified time in the respective states.

"With the conclusion that the controlling rule is that of the common law, the Benson case and the Rosen case do not conflict; but both cases reject the notion, which the [Reid case seems] to accept, that the courts, in the face of greatly changed conditions, are still chained to the ancient formulae and are powerless to declare and enforce modifications deemed to have been wrought in the common law itself by force of these changed conditions." 
ing federal common law..$^{26}$ A clarification of what the Reid case stands for shows that it need not cause these difficulties.

The principles implicitly or expressly laid down by the Reid case may be separated as follows: (I) that Congress could prescribe the rules as to competency of witnesses which should be followed in the federal courts; (2) that Congress did not direct the federal courts in criminal cases to follow contemporary state rules of evidence; (3) that Congress had impliedly directed the federal courts to follow those rules of the common law in force "in the respective states" ${ }^{27}$ at the time the Judiciary Act of ${ }_{77} 89$ was passed; (4) that state statutes passed subsequent to 1789 would not be binding upon the federal courts. If there is any inconsistency between the Reid case on the one hand and the Rosen and Funk cases on the other, it must result from the implied Congressional mandate that the federal courts were to follow the rules of evidence in force in the re-

${ }_{26}$ The following quotation from an article written before the Funk case was decided concretely illustrates this difficulty:

"No case was cited in the opinion [of the Rosen case] . . . in which a court without express legislative authority abolished the common law disqualification. .... And independent investigation has failed to reveal such a case. The Rosen case must, therefore, rest upon the principle that state legislation, whose tendency perhaps has been followed in federal legislation not directly applicable to the case in hand, creates a weight of authority which the federal courts may and must follow. That such a holding is revolutionary need hardly be suggested." Leach, State Law of Evidence in the Federal Courts, 43 Harv. L. Rev. 554, 562 (r930).

Though it is often said that there is no federal common law, a realistic view must recognize it exists in the sense of "a-general common law existing throughout the United States, not, it is true as a body of law distinct from the common law enforced in the states, but as containing the general rules and principles." Western Union Telegraph Co. v. Call, I8I U.S. 92, 2 I Sup. Ct. 56 r, 45 L. Ed. 765 (rgor).

${ }^{27}$ It is not altogether clear what the Reid case meant by this phrase. On the one hand there is strong language in the case which specifically refers to the law of the individual state. On the other hand, in support of the view that a general body of common law was meant (see supra, note 26), it may be suggested (I) that the state laws were uniform at the time the Reid case was adopted and that the court consequently did not have a situation before it which required more precise language; (2) Swift v. Tyson, I6 Pet. I, Io L. Ed. 865 (1842) had been on the books for ten years, holding that common law decisions in the individual states did not control the federal courts in certain substantive law fields. It seem incongruous to consider the federal courts not bound to follow individual state rules when substantive law is involved and a statute expressly directs the court to consider the "laws of the several states" as rules of decision (see supra, note Io, c. for full text of the statute), and yet hold that when rules of evidence are involved, the laws of the individual states must be followed in the federal courts, even though the statute involved in Swift $v$. Tyson was held inapplicable.

If this phrase is construed to have meant a general common law, Logan v. United States supra note 24, may be treated as having applied the same rule as the Reid case, since it could be held to prevail in each state upon entering the Union, not as the common law of the state, but as the general common law of the whole country. Whether the Logan case adopts a distinct rule for the newer states or merely applies the rule of the Reid case, and whether the Reid case adopts the rules of the individual states or a general body of common law does not affect the validity of the subsequent analysis. The view will be adopted, however, that a general common law was adopted by the Reid case and that the Logan case is not inconsistent with it. The recent cases so treat it. Funk v. United States, 290 U.S. 37x, 54 Sup. Ct. 212; Wrolfle v. United States, 290 U.S. 6r7, 54 Sup. Ct. 279 (1934). 
spective states in $\mathrm{r}_{7} 89$, since all three cases are in accord as to the other principles. Clearly if the Reid case is to be interpreted as deciding that the rules of evidence in the federal courts were anchored unchangeably as they existed in I 789 unless Congress chooses to modify them, the Funk case is inconsistent, since it changes a common law rule without Congressional action in permitting a spouse to testify in a criminal trial. ${ }^{28}$

That the Reid case should not be so interpreted can be shown by comparing it to express statutory adoptions of the common law such as the Illinois statute ${ }^{29}$ .... The common law of England so far as the same is applicable and of a general nature, and all statutes .... prior to the fourth year of James the First .... shall be the rule of decision.....

It has never been intimated that this section, which is substantially enacted or judicially adopted in most of the states of the Union, crystallizes the rules of evidence as of the time of James the First, or of the adoption of such statute, and permits no additions or modifications. $3^{\circ}$ On the contrary, as both the Funk and Rosen case recognize, one of the essential principles of the common law is the * power of growth. ${ }^{3 x}$

If Congress, therefore, by a similar provision had in express words directed the federal courts to follow the common law rules of evidence as they existed in the respective states in $I 789$, it can hardly be questioned that such a statute would not have been construed to paralyze the common law into immobility. What the Reid case did, was to find by implication what such a statute would have provided expressly. And there is no reason for holding the common law to be unchangeably fixed because of an implied adoption when an express adoption would permit growth and change.

${ }^{28}$ Funk v. United States, supra note 20 . In reaching this result Justice Sutherland re-examined the bases of the spouses' disqualification at common law-interest and public policy(see supra, note 5) and showed their inapplicability in the light of "legislation and modern thought." Competency of a wife to testify against her husband was not involved, and the court expressly refused to decide that question.

The Funk case overrules Jin Fuey Moy v. United States, 254 U.S. 189 , 4 I Sup. Ct. 98,65 L. Ed. 214 (1920) which did not cite the Rosen case as necessitating any change. See also Hendrix v. United States, 219 U.S. 79, 3I Sup. Ct. I93, 55 L. Ed. I02 (r910).

${ }^{29}$ Ill. Cahill's Rev. Stat. (r933), c. 28.

${ }^{30}$ On the contrary, as an Illinois court has pointed out in discussing this statute:

“. . . . they [the English courts] have made many innovations upon its original principles, and .... many of them have become much modified or wholly changed. The courts of the severai States have also taken advantage of its pliant nature, in which consists one of its greatest excellencies, and adapted it to the evervarying exigencies of the country, and to the everchanging conditions of society. This results from necessity; and in our further progressive improvement, other and more extensive modifications will be effected." Boyer v. Sweet, 3 Scam. (III.) 120 (I84I).

${ }^{3 x}$ The Rosen case itself shows this most strongly since without a statute it overthrew what was unquestionably the common law rule of 1789 by holding a convicted felon to be a competent witness; and the Funk case stresses the same point: The "rules [of the common law] are modified upon its own principles and not in violation of them." (Cited from People v. Randolph, 2 Park. Cr. Rep. (N.Y.) I74, I77). 
The Reid case in short, must be understood to have enunciated a simple, sensible rule-Congress had directed the federal courts to follow in criminal cases the rules of evidence of the common law of 1789 . One of the essential principles of the law thus adopted as a rule of decision was the capacity to change and grow.

With this rule of the Reid case, the holdings in the Rosen and Funk cases do not conflict. They exemplify it; and reaffirm its validity. And in the light of this analysis the apparent dilemma of state statutes becoming federal common law dissolves, ${ }^{32}$ since in the process of growth the common law may be influenced by the same philosophical ideas and societal changes which lead legislatures to pass statutes abolishing disqualifications of witnesses. That the legislature reacts more quickly to the stimuli should not be considered to preempt the field and to inhibit the natural development of the common law so as to prevent it from reaching the same result. In fact it is entirely proper for the courts to consider widespread legislation as one of the best indications that societal opinion has been modified.

Thus understood the words of the court in the Funk case take on a new significance when they state:

The final question to which we are thus brought .... is the question of the power of these courts, in the complete absence of congressional legislation on the subject, to declare and effectuate upon common law principles, what is the present rule upon a given subject in the light of fundamentally altered conditions, without regard to what has previously been declared and practiced. It has been said so often as to have become axiomatic that the common law is not immutable but flexible, and by its own principles adapts itself to varying conditions.

If adhered to in its unconfused simplicity, the same principle will occasion no difficulty in years to come when further changes necessitate reconsideration of present rulés of evidence. 33

AdolPH A. RuBINSON

\section{THE VALIDITY OF AGREEMENTS BY BANKS TO REPURCHASE SECURITIES}

The case of Knass v. Madison \& Kedzie State Bank $k^{\mathrm{r}}$ is a typical sequel to certain banking excesses of the last decade. ${ }^{2}$ Defendant bank had sold securities to complainant, and had agreed to repurchase ${ }^{3}$ the securities at par or a slight dis-

${ }^{32}$ Supra, note 26.

${ }_{33}$ The potentialities of the Funk case can already be discerned in the recognition of its application to rules of admissibility of testimony other than those relating to competency of witnesses. Wolfle v. United States, 290 U.S. 6I7, 54 Sup. Ct. 279 (r934).

${ }^{ } 354$ IIl. 554, r88 N.E. 836 (1933).

2See Fribourg, The New York Mortgage Bond Situation, The Annalist (Dec. 22, 1933), 803; Williams, The Future of Mortgage Banking, Great Lakes Banker (Feb. 1934), 3.

3 The agreements were signed by a vice-president of defendant bank, generally without any designation of official position or descriptio personae. 